\title{
Analysis on the Impact of Shopping Online on the Real Economy
}

\author{
Siyuan Fan ${ }^{1, *}$ \\ ${ }^{1}$ University of Connecticut, Storrs, CT, 06269, US \\ *Corresponding author. Email: siyuan.fan@uconn.edu
}

\begin{abstract}
Shopping online is a new convenient shopping way. Shopping apps like amazon, farfetch, and Taobao attract more and more consumers. The main reasons for consumers choosing online-shopping are as follows: Consumers have more choices of products. In addition, they can shop at any time and any place and they can save time and money. As more and more consumers use this new way, there are some non-negligible consequences on the real economy. The purpose of this paper is to figure out the influences on the real economy. There are four negative influences. Firstly, the lower cost of online stores will increase the bankruptcy of small and medium-sized enterprises. Secondly, online stores have lower demands of entity stores, which will affect the real estate industry. Thirdly, the wastage rate of staff in online stores is high. Fourthly, because of the lower cost of online stores, they can lower the price of the products. However, it is difficult to make sure that all prices are above price floor. In this situation, vicious competition may appear in the market. Besides, there is one positive influence that the online store has less restriction of area, so shopping online relieves the pressure on the market to stock up in some situations.
\end{abstract}

Keywords: Shopping online, Bankruptcy, Real estate industry, Unemployment, Vicious competition.

\section{INTRODUCTION}

Based on National Public Ratio, there are 69\% of Americans have shopped online and global online shopping market size will hit more than $\$ 4$ trillion in 2020 [1]. Especially in 2020, consumers prefer shopping online to avoid going to public places to interact with other people. Adobe Analytics shows spending online on Black Friday in 2020 surged nearly $22 \%$ to hit a new record. Consumers spent $\$ 6.3$ million per minute online. The expenditure on smartphones surged $25.3 \%$ and reached $\$ 3.6$ billion, which accounts for $40 \%$ of total e-commerce spending [2]. Online shopping has changed the way of shopping and payment for many consumers, which means shopping malls will face customer churn. The above data show that the amount of online shopping and consumer groups is gradually increasing. And this new way of shopping is also having an impact on the real economy. The main purpose of this paper is to study and discuss the negative and positive effects of online shopping on the real economy, and to further explore the causes and results of these impacts.

\section{NEGATIVE INFLUENCE ON REAL ECONOMY}

\subsection{Bankruptcy of Small and Medium- sized Enterprises}

The increase in online shopping, along with fiercer competition in the market, will lead to the bankruptcy of small and medium-sized enterprises. There are two main reasons: 1 . In the demand and supply curve graph, when new suppliers enter the market, the supply curve will shift right, which means the quantity supplied will increase and the market price will decrease ( $\mathrm{S}$ to $\mathrm{S} 1$ and $\mathrm{p}$ to $\mathrm{p} 1$ ). For the demand curve, when some online sale channels provide substitutes or similar products at a lower price, which means the price of substitute goods decreases, the curve will shift to the left (D to D2). In this situation, the equilibrium price will be lower. Since Total Profit= Total Revenue - Total 
Cost, producers have to decrease their profit to attract more consumers.

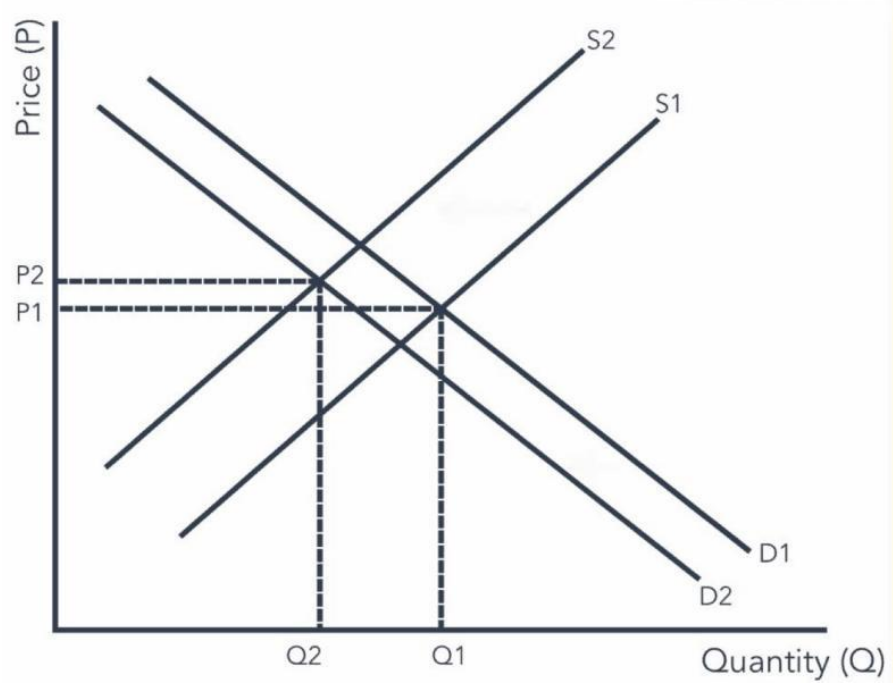

Figure 1 Demand and supply curve graph.

Consumers seldom have brand loyalty to the brands of some small and medium-sized enterprises. Brand loyalty tends to occur in some big and old brands. Brand loyalty helps firms have stable consumers and revenue when they compete with other brands that have similar products. The data also shows the bankruptcy of small and medium-sized enterprises. Nearly 31 percent of small businesses in the U.S. are currently not operational based on the latest small business statistics. However, small and medium-sized enterprises are also very important to the development of the economy. The proportion of small and medium-sized enterprises in the number of enterprises cannot be ignored. The tax revenues and jobs they create also boost the economy. In the world, there is over 90 percent of the business population represents small- and medium-sized businesses [3]. Small- and medium-sized businesses are the main force to develop the economy in the US. There are more than twentyseven million small businesses and they generate about 50 percent of GDP in the US.[4] Besides, the risk and failure of small and medium-sized enterprises will harm the motivation of entrepreneurs. Entrepreneurship has a huge positive influence on the development of the economy. Firstly, entrepreneurship creates innovation in the market. Constant innovation and the development of new technologies is one of the driving forces to improve the productivity of contemporary society. When entrepreneurs are ready to start a business, they need new technology or innovation in some aspect as their competitive factor in the market. When a new competitive company enters the market, it stimulates the innovation and development of existing companies to ensure that they are not eliminated by the market. Secondly, It has also made certain contributions to the progress and development of society. Large enterprises are often entrepreneurial step by step to adapt to market innovation and development. The current network era is also based on the start-up and development of computer and network companies. It is the continuous innovation and invention of entrepreneurs that promote the continuous progress of society and economic growth. However, starting a business always means that the entrepreneur or a team of entrepreneurs starts a small business and then grows and grows, which means that the challenges and risks faced by entrepreneurs will be the same as those faced by entrepreneurs. When there is too much risk, low profit, and fierce competition in the market, people are going to be hesitant about starting a business.

\subsection{Affecting the Real Estate Industry}

It should not be ignored that the impact of online shopping on shopping centers also affects the real estate industry. First of all, for the same goods, physical stores cannot offer lower prices than online stores, because the costs of physical stores are constantly rising, including land rent, freight, labor costs, store decoration costs and each middleman's profit share. Therefore, brick-andmortar stores do not have an advantage on price. If these stores keep the same prices, they are bound to lose customers, which means there will be less demand. If they lower their prices to attract 
customers, the average profit will be lower. It's hard for brick-and-mortar stores to stay in business. When the operation of physical stores is faced with problems, the operators often choose to close the physical stores. That means there will be a glut of physical rentals. Based on the data, a record net decline $(-9,877)$, number of closures $(17,532)$, and a new low in the number of store openings $(7,655)$. That's equivalent to an average of 48 chain stores closing every day, and only 21 openings. [5]

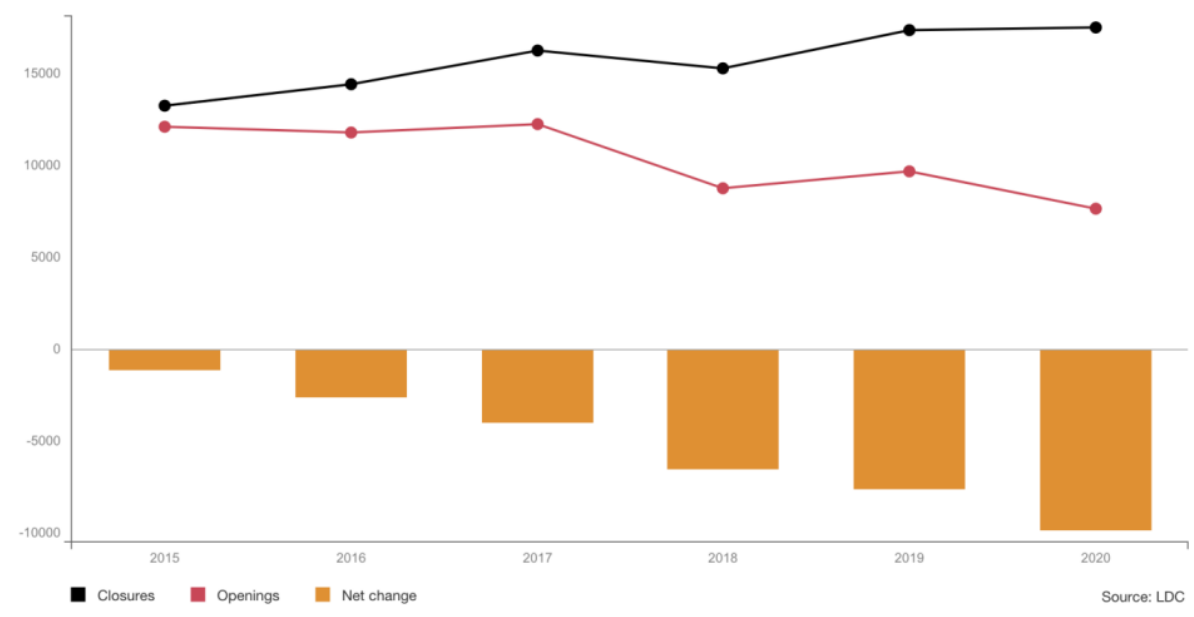

Figure 2 Data of closure and openings.

From the perspective of consumers, going to California to buy a VR will waste a lot of costs, such as airline tickets, time spent on the road, and opportunity cost. Some huge malls have closed in recent years. USA TODAY has pinpointed that Macy's will be shuttering around 125 stores over three years in 2020 [6]. And in 2017 JCPenney plans to shutter as many as 140 stores in the coming months. [7] Moreover, the continuous closure of large shopping malls will affect the real estate industry. Real estate is an obligatory part of the American economy. Housing construction contributed \$1.15 trillion to U.S. economic output and accounted for 6.2 percent of U.S. gross domestic product in 2018 [8]. Most Americans have their own homes. Houses not only provide places to live for the owners but also account for a large part of the owners' wealth. When the housing price rises, the owners' wealth increases, and their purchase power also increases, which will be beneficial to the development of the national economy. Besides, real estate and its derivatives are also hot investments for many Americans. When the development of the real estate industry is negatively affected, investors' income will be reduced and their expenditure will be correspondingly reduced. Finally, the housing mortgage loan is also the choice of many people, when the real estate industry is impacted, the national economy will be impacted. The 2008 financial crisis is a powerful illustration of the impact of the housing industry on the American economy.

\subsection{Unemployment Will Increase}

Small and medium-sized enterprises and shopping malls provide lots of job opportunities. Small companies create 1.5 million jobs annually and account for 64 percent of new jobs created in the U.S based on the Small Business Administration in 2019. [5] The impact of online shopping on small and medium-sized enterprises and shopping malls has reduced employment opportunities in many industries, like construction and services industries. In real estate, shopping malls require architects and engineers to build and design plans. In the service sector, malls need to employ a large number of sales and service personnel to ensure that consumers can get good service. With the increase in unemployment, there will be negative influences on economy. The purchasing power of consumers is positively correlated with income. When consumers lose their jobs and their incomes fall, so does their ability to buy. In the demand-supply curve, the demand curve shift left, which means the equilibrium quantity and price will decrease. Since the decrease in quantity demand, the market will be forced to hoard its products. There will be more supply than demand, which causes deflation. The rise in unemployment will widen the gap between the rich and the poor in society. Secondly, the national tax revenue 
decreases, and the financial burden increases. The government needs money to guarantee the minimum standard of living for the unemployed, and the government will have less tax. GDP will decrease when the number of products purchased in the market falls.

\subsection{Vicious Competition in Real Economy}

Vicious competition may appear in real economy. Consumer preference influence what they will choose. Most consumers, prefer buying at low prices when the products are similar. In the demand and supply curve graph, quantity demand will increase as the decrease in the price. We have learned that one firm with a lower price in the market will attract all consumers and earn profit in game theory. Based on there is no price floor for some products on some online shopping websites, vicious competition is possible to appear in the market, which has a negative influence on the real economy. In this situation, suppliers will try to make their prices as low as possible. When firms start "Price War", vicious competition also followed. There are two main negative influences of vicious competition: Firstly, disturbing the normal price order of the market is not conducive to the optimal allocation of social resources. The price of the market changes with the change of market supply and demand relations, which has a guiding role in the allocation of social resources. When vicious competition occurs in the market, the price order of the market will be disturbed and the allocation of social resources will be affected. 2 . Secondly, hindering the normal development, innovation, and progress of the industry and harms the rights and interests of consumers. When some enterprises begin to engage in vicious price competition, other enterprises in the industry will be forced to reduce their prices. Due to the decrease in profits, enterprises will reduce other costs, such as the cost of technology and product development, to ensure the normal operation of enterprises. As a result, consumers cannot buy products of higher technology and quality.

\section{POSTIVE INFLUENCE}

\subsection{Pressure on the Market to Stock Up in Some Situations}

On the positive side, it provides a direct channel for consumers and producers. This channel relieves the pressure on the market to stock up in some situations. In this year's epidemic period, online shopping also highlighted the importance of economic development. It is hard to imagine how many products will be stockpiled when consumers are making fewer trips to brick-and-mortar stores and there is no such thing as online shopping. Online sales provide the channel through which producers can sell their products. Secondly, it also stimulates the economic development of some remote areas and reduces the gap between the rich and the poor. Since there is no regional restriction on online shopping, it also provides a channel for some remote areas to sell local specialties. In the absence of an online distribution channel, it is difficult to sell products directly in remote areas and often requires the acquisition and re-sale of products by some intermediary distributors. Intermediary distributors will buy their products at a lower price and re-sale in the market, which means the producers will get a lower income. When producers can sell their products directly online, their direct revenues will be higher. We can figure out in this picture, there will be no factory market and product market through online shopping, households can buy products from businesses directly. [9]This is because the online sales channel reduces the profit-sharing of intermediate distributors. 

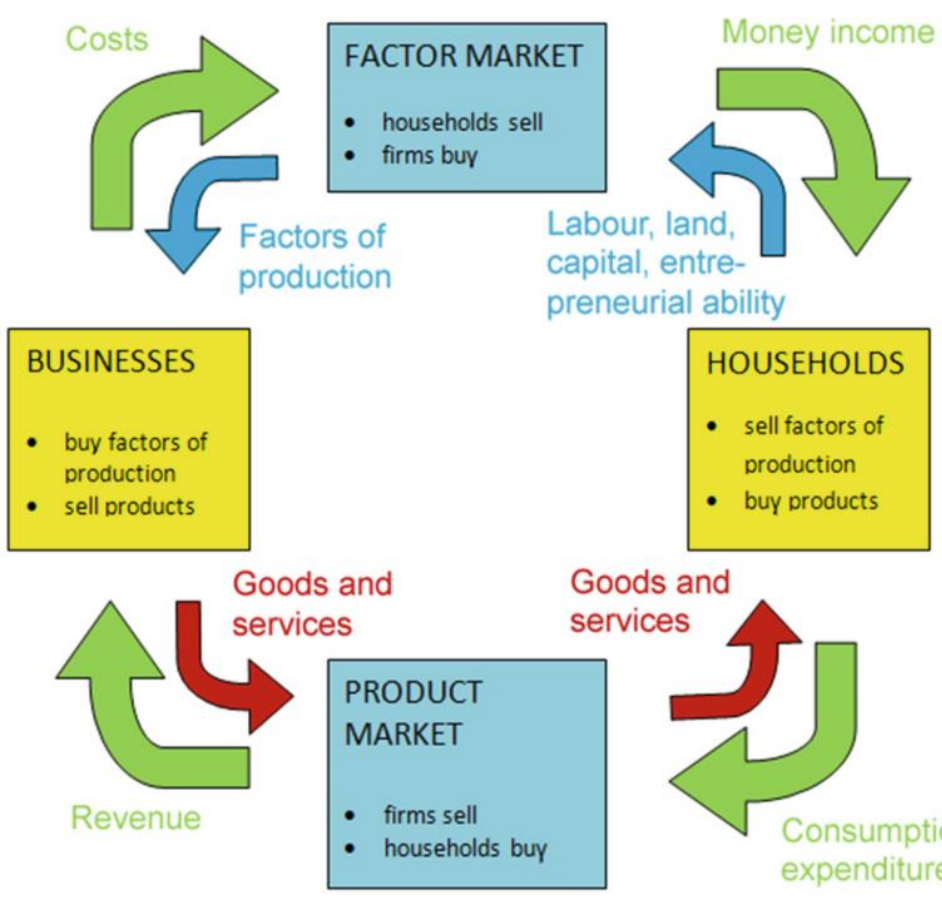

Goods and services

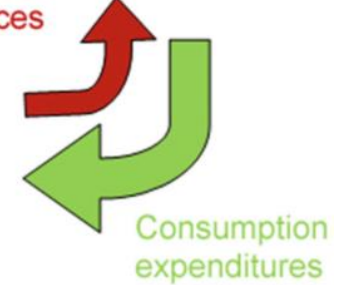

Figure 3 Market cycle.

\section{CONCLUSION}

In general, shopping online has negative and positive influences on real economy. In negative aspects, the low-cost advantage of online stores makes small and medium-sized enterprises face the risk of bankruptcy, thus discouraging the enthusiasm of entrepreneurship. Second, online stores have very low demand for physical stores, so the impact of online stores leads to a decrease in the demand for physical stores. Thirdly, the demand for manpower of online stores is less than that of offline stores, and the rapid development of online stores has a certain impact on the demand for manpower of some offline service industries, which leads to the increase of the unemployment rate. Finally, the price of online stores can hardly be guaranteed to be above the price floor. In order to attract more consumers, some merchants will keep lowering the price, which leads to vicious competition.

\section{AUTHORS' CONTRIBUTIONS}

This paper is independently completed by Siyuan Fan.

\section{ACKNOWLEDGMENTS}

First and foremost, I would like to express my deepest gratitude to the professors and teaching assistants of this research, who have given me valuable guidance at every stage of writing this paper. In addition, I would like to thank the professors in the university course, whose course gave me the basis of professional knowledge for this paper.

\section{REFERENCES}

[1] Tyko, Kelly. Macy's Is Closing 125 Stores with the First Locations Closing Soon: Is Your Location on the Map? USA Today, Gannett Satellite Information Network, 7 Feb. 2020, www.usatoday.com/story/money/2020/02/06/ macys-store-closures-2020-map/4681959002/.

[2] Lauren Thomas. B Black Friday 2020 Online Shopping Surges $22 \%$ to Record \$9 Billion, Adobe Says.। CNBC, CNBC, 28 Nov. 2020, www.cnbc.com/2020/11/28/black-friday2020-online-shopping-surges-22percent-torecord-9-billion-adobe-says.html.

[3] Mohsin, Maryam. 10 Small Business Statistics You Need to Know in 2020. Oberlo, Oberlo, 11 Dec. 2020, www.oberlo.com/blog/smallbusiness-statistics.

[4] Office of Advocacy, U.S. Small Business Administration, The Small Business Economy: A Report to the President, Appendix A December 2010 https://cdn.advocacy.sba.gov/wp- 
content/uploads/2019/03/26121943/FY-2020Congressional-Budget-Justification-and-FY2018-Performance-Report.pdf

[5] Price water house Coopers. "Store Openings and Closures - 2021." PwC, www.pwc.co.uk/industries/retailconsumer/insights/store-openings-andclosures.html

[6] Gilbert, Nestor. 74 Compelling Online Shopping Statistics: 2020 Data Analysis \& Market Share. Financesonline.com, FinancesOnline.com, 4 May 2020, financesonline.com/online-shoppingstatistics/.

[7] The department store chain did not disclose how many jobs would be cut. JCPenney to Close up to 140 Stores. CNNMoney, Cable News Network, money.cnn.com/2017/02/24/news/companies/j cpenney-closing-stores/index.html.

[8] Amadeo, Kimberly. Why Buying a Home Helps Build the Nation. The Balance, www.thebalance.com/how-does-real-estateaffect-the-u-s-economy-3306018

[9] Lopiccolo, Venita H. "Economic Utilities Created By Business Activities.” Oxynux.Org, 4 Mar. 2018, www.oxynux.org/economicutilities-created-by-business-activities.html

[10] Heather Mcpherson. Here's Why Small Business Matters. U.S. Chamber of Commerce, 27 Nov. 2018, www.uschamber.com/series/above-thefold/heres-why-small-business-matters. .

[11] FOR IMMEDIATE RELEASE. U.S. Census Bureau News, U.S. Department of Commerce, $19 \quad$ Nov. 2020, www.census.gov/retail/mrts/www/data/pdf/ec _current.pdf

[12] Valentino Pian. EMPLOYMENT. Employment: a Key Concept in Economics, 2001, economicswebinstitute.org/glossary/employ.ht $\mathrm{m}$.

[13] The Importance of Small Business to the U.S. Economy. Exploring Business, University of Minnesota Libraries Publishing Edition, 2016. This Edition Adapted from a Work Originally Produced in 2010 by a Publisher Who Has Requested That It Not Receive Attribution. 8
Apr. 2016 , open.lib.umn.edu/exploringbusiness/chapter/5 -2-the-importance-of-small-business-to-the-us-economy/.

[14] Amadeo, Kimberly. Why Buying a Home Helps Build the Nation. The Balance, www.thebalance.com/how-does-real-estateaffect-the-u-s-economy-3306018.

[15] The Importance of Small Business to the U.S. Economy, saylordotorg.github.io/text_exploringbusiness-v2.0/s09-02-the-importance-ofsmall-busine.html.

[16] Sandile "StartupGuy" Shabangu Follow Startup Guy at Startup Mzansi FoundationLike46Comment2ShareLinkedInFa cebookTwitter1, et al. THE IMPORTANCE OF STARTUP COMPANIES FOR ECONOMIC DEVELOPMENT. LinkedIn, www.linkedin.com/pulse/2014112208442877551011-the-importance-of-startupcompanies-for-economic-development.

[17] Baijal, Rahul. 4 Reasons Why Entrepreneurship Is Important. Entrepreneur, 20 Jan. 2016, www.entrepreneur.com/article/269796.

[18] FOR IMMEDIATE RELEASE. U.S. Census Bureau News, U.S. Department of Commerce, 19 Nov. 2020, www.census.gov/retail/mrts/www/data/pdf/ec _current.pdf. 